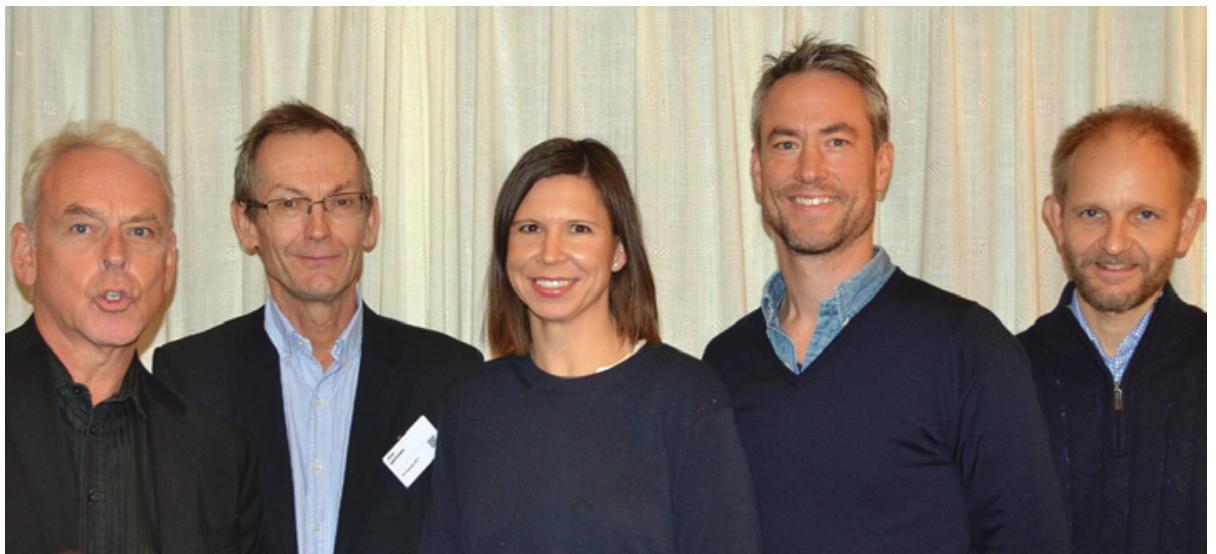

Fra venstre Jon Kristinsson, Jøran Hjelmesæth, Hilde Risstad, Torgeir Søvik, Tom Mala. Foto: Hira Afta

\title{
Hvilken gastrisk bypassmetode er best?
}

Distal gastrisk bypass gir ikke bedre resultater enn standard gastrisk bypass hos pasienter med alvorlig fedme, viser en ny norsk studie.

Gastrisk bypass er en av de vanligste typene vektreduserende kirurgi som benyttes i dag. Ulike varianter av denne operasjonsmetoden er blitt utviklet for å øke vekttapet og effekten på fedmerelatert sykdom. Ved distal gastrisk bypass blir fordøyelsesenzymer tilført lenger ned i tynntarmen enn ved standard gastrisk bypass, der den delen av tarmen hvor næringsopptaket hovedsakelig foregår, blir forkortet. Dette kan føre til mindre næringsopptak og dermed større vekttap. I en studie som nylig er publisert i tidsskriftet JAMA Surgery har norske forskere sammenlignet effektene av to ulike fedmekirurgiske inngrep (1).

113 pasienter med alvorlig grad av fedme, definert som kroppsmasseindeks på 50-60 $\mathrm{kg} / \mathrm{m}^{2}$, ble randomisert til distal eller standard bypassoperasjon. Etter to år var det ingen forskjell i vekttap mellom de to gruppene. Antallet komplikasjoner var sammenlignbart, men noen pasienter med distal gastrisk bypass utviklet bivirkninger relatert til malabsorpsjon.

- Dette er et overraskende funn ettersom tidligere forskning har antydet at varianter av distal gastrisk bypass gir større vekttap, sier Hilde Risstad, som er artikkelens førsteforfatter. - Etter en samlet vurdering av alle funnene mener vi at distal gastrisk bypass ikke gir store fordeler sammenlignet med standard gastrisk bypass, som er en veletablert metode. Vi ser derfor ingen grunn til å anbefale distal gastrisk bypass hos pasienter med svært høy kroppsmasseindeks, sier hun.

- Det finnes ulike varianter av distal gastrisk bypass, og andre varianter kan gi andre resultater. Vi skal følge pasientene videre i minst fem år og er spente på å få svar på om resultatene endrer seg over tid, sier Risstad.

\section{Samarbeid mellom \\ to norske sykehus}

Studien er et samarbeidsprosjekt mellom to av de største regionale senterne som behandler sykelig fedme i Norge, nemlig Senter for sykelig overvekt i Helse Sør-Øst ved Oslo universitetssykehus og Senter for sykelig overvekt i Helse Sør-Øst ved Sykehuset $\mathrm{i}$ Vestfold.

Studien inngår som en del av doktorgradsarbeidet for førsteforfatterne Hilde Risstad og Marius Svanevik. Prosjektlederne Rune Sandbu og Tom Mala har sammen med Jon Kristinsson og Jøran Hjelmesæth vært sentrale i planleggingen og gjennomføringen av studien.

\section{Kaveh Rashidi \\ Tidsskriftet}

\section{Litteratur}

1. Risstad H, Svanevik M, Kristinsson JA et al. Standard vs distal roux-en-Y gastric bypass in patients with body mass index 50 to 60: a double-blind, randomized clinical trial. JAMA Surg. doi: 10.1001/ jamasurg.2016.2798. E-publisert 14. september 2016
Ordforklaringer

Gastrisk bypass: Operasjonsmetode der det lages en liten magesekklomme og deler av tynntarmen forbikobles.

Kroppsmasseindeks: Et indirekte mål for mengden kroppsfett som beregnes ut fra en persons høyde og vekt.

Malabsorpsjon: Redusert opptak av næringsstoffer fra tarmen.

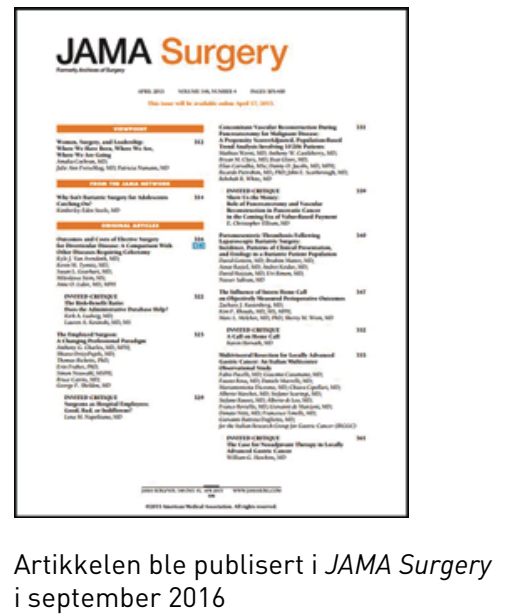
i september 2016 